\title{
KARAKTERISTIK PELAKU MOBILITAS PENDUDUK ULANG ALIK DI WILAYAH PERI URBAN Studi di Kecamatan Mangkubumi (Kota Tasikmalaya) dan Kecamatan Singaparna (Kabupaten Tasikmalaya)
}

\author{
Elgar Balasa Singkawijaya \\ Program Studi Pendidikan Geografi \\ Universitas Siliwangi \\ elgar@unsil.ac.id
}

\begin{abstract}
ABSTRAK
Mobilitas penduduk adalah suatu bentuk pergerakan dan perpindahan penduduk antar wilayah yang dipengaruhi oleh waktu serta memiliki maksud dan tujuan tertentu. Pergerakan dan perpindahan ini menggunakan moda transportasi yang berfungsi sebagai alat penghubung untuk memberikan kemudahan (aksesibilitas) antar wilayah. Lokasi penelitian di Kecamatan Mangkubumi (Kota Tasikmalaya) dan Kecamatan Singaparna (Kabupaten Tasikmalaya) secara kesatuan merupakan wilayah peri urban. Kedua kecamatan ini secara kewilayahan saling berdampingan dan berinteraksi. Permasalahan dalam penelitian ini adalah (a) karakteristik demografis yang melakukan mobilitas ulang alik di wilayah peri urban dan (b) bentuk sosial ekonomi pelaku mobilitas penduduk ulang alik di wilayah peri urban. Metode penelitian yang digunakan adalah metode kualitatif. Narasumber sebagai sampel dalam penelitian dipilih berupa individu yang latar belakang pekerjaan dan melakukan mobilitas ulang alik berjumlah 18 orang yang dibagi menjadi 4 kelompok wilayah yaitu 3 orang pada zona bidang desa (Zobides), 7 orang pada zona bidang desa kota (Zobidekot), 5 orang pada zona bidang kota desa (Zobikodes) dan 3 orang pada zona bidang kota (Zobikot). Teknik pengumpulan melalui observasi dan wawancara. Teknik pengolahan data melalui tahapan persiapan pengumpulan data dan penyeleksian data. Analisis data yang digunakan melalui reduksi data dan triangulasi. Hasil penelitian menunjukkan (1) Karakteristik penduduk berdasarkan demografis dari jenis kelamin wanita lebih banyak dibanding pria, usia paling banyak 25-29 tahun, status perkawinan yang sudah menikah, latar belakang keluarga sebagai pendatang dan bukan pendatang dan pelaku mobilitas bagian dari keluarga dan (2) karakteristik sosial terdiri dari tingkat pendidikan strata 1 (sarjana) dan sebagaian besar jenis pekerjaan adalah wirausaha; dan karakteristik ekonomi secara tingkat pendapatan tahunan Rp. 21.000.000-Rp. 30.000.000.
\end{abstract}

\section{Kata Kunci : Mobilitas, Penduduk Ulang Alik, Peri Urban}

\section{PENDAHULUAN}

Dalam memenuhi kebutuhan hidupnya, manusia melakukan mobilitas dari satu tempat ke tempat yang lainnya, seperti dari pemukiman (perumahan) ke tempat bekerja, sekolah, belanja dan lain - lain. Mobilitas penduduk adalah suatu bentuk pergerakan dan perpindahan penduduk antar wilayah yang dipengaruhi oleh waktu serta memiliki maksud dan tujuan tertentu. Pergerakan dan perpindahan ini menggunakan moda transportasi yang berfungsi sebagai alat penghubung untuk memberikan kemudahan (aksesibilitas) antar wilayah. Mobilitas penduduk ada karena kebutuhan hidup manusia tidak selalu dapat terpenuhi oleh kemampuan wilayah dimana ia bertempat tinggal. Mobilitas 
penduduk terjadi antara lain karena adanya perbedaan potensi dan kemampuan wilayah yang satu dengan yang lain didalam memenuhi kebutuhan hidup penduduknya. Hal ini menunjukkan kenampakan wilayah secara diferensiasi area, yang secara karakteristik berbeda antara yang satu dengan yang lainnya namun saling berinteraksi.

Pada dasarnya manusia melakukan mobilitas dengan suatu tujuan yaitu untuk meningkatkan kualitas hidupnya mulai dengan pemenuhan kebutuhan pangan sekunder lainnya, dengan kata lain dapat dinyatakan bahwa seseorang akan melakukan mobilitas dengan tujuan untuk memperoleh pekerjaan akan pendapatan. Dengan demikian daerah tujuan mobilitas penduduk merupakan daerah dimana terdapat peluang yang lebih besar untuk memperoleh pekerjaan yang lebih baik, atau peningkatan pendapatan.Secara fisik proses restrukturisasi ditandai dengan perubahan penggunaan lahan baik di pusat kota ini maupun pinggiran kota. Kawasan pusat kota mengalami perubahan penggunaan tanah yang sangat intensif dari kawasan tempat tinggal menjadi kawasan bisnis, perkantoran, perhotelan dan sebagainya. Di lain pihak, di kawasan pinggir kota terjadi alih fungsi (konversi) penggunaan tanah secara besar-besaran dari tanah pertanian subur ke kawasan industri dan permukiman skala besar (Firman : 1996). Wilayah pinggiran kota yang mengalami pertumbuhan dan perkembangan, pada akhirnya memunculkan bentuk wilayah yang bias. Munculnya bias wilayah ini disebabkan oleh percampuran dan perubahan struktur wilayah antara kota dan desa. Di satu sisi kota menunjukkan sifat fisik desa dan desa menunjukkan sifat fisik kota. Dari karakteristik percampuran wilayah kota - desa dan sifat fisik tersebut maka dikenal dengan istilah wilayah peri urban.

Kecamatan Mangkubumi - Kota Tasikmalaya dan Kecamatan Singaparna Kabupaten Tasikmalaya, secara kesatuan merupakan wilayah peri urban. Kedua kecamatan ini secara kewilayahan saling berdampingan dan berinteraksi. Hal ini ditandai dengan adanya pertumbuhan jumlah penduduk, perkembangan permukiman, alih fungsi lahan dari agraris menjadi non agraris, pertumbuhan kegiatan ekonomi dengan skala mikro dan mobilitas penduduk ulang alik yang sangat tinggi.

\section{PERMASALAHAN}

Permasalahan dalam penelitian ini adalah sebagai berikut :

a. Bagaimanakah karakteristik demografis yang melakukan mobilitas ulang alik di wilayah peri urban?

b. Bagaimanakah karakteristik sosial ekonomi pelaku mobilitas penduduk ulang alik di wilayah peri urban.

\section{TUJUAN}

Tujuan penelitian dalam penelitian ini adalah sebagai berikut :

a. Mengetahui karakteristik demografis yang melakukan mobilitas ulang alik di wilayah peri urban

b. Mengetahui karakteristik sosial ekonomi pelaku mobilitas penduduk ulang alik di wilayah peri urban. 


\section{KAJIAN PUSTAKA}

Mobilitas penduduk berkaitan erat dengan gerak dan perpindahan penduduk. Dalam hal ini gerak merupakan proses pindah dari tempat satu ke tempat yang lainnya. Mobilitas penduduk (population mobility) secara lebih khusus territorial mobility yang biasanya mengandung makna pergerakan spasial, fisik, dan geografis yang termasuk ke dalam mobilitas penduduk permanen dan maupun non permanent (Rusli : 1996). Menurut Tamin (1997) pola pergerakan di bagi dua yaitu pergerakan tidak spasial dan pergerakan spasial. Konsep mengenai pergerakan tidak spasial (tanpa batas ruang) di dalam kota, misalnya mengenai mengapa orang melakukan pergerakan, kapan orang melakukan pergerakan, dan jenis angkutan apa yang digunakan. Sedangkan pergerakan spasial adalah pergerakan yang dipengaruhi tata guna lahan yang terdapat di dalam suatu wilayah. Dalam hal ini, konsep dasarnya adalah bahwa suatu perjalanan dilakukan untuk melakukan kegiatan tertentu di lokasi yang dituju, dan lokasi tersebut ditentukan oleh tata guna lahan kota tersebut.

Mobilitas penduduk menurut Mantra (1985), dan Sumaatmadja (1981) yaitu semua gerak penduduk secara spasial dalam waktu tertentu dan batas wilayah administrasi untuk memenuhi kebutuhan ekonomi maupun untuk memenuhi kebutuhan sosial lainnya. Sedangkan menurut Tukiran (2002) mobilitas penduduk adalah perpindahan penduduk dari suatu daerah ke daerah lain atau dari suatu tempat ke tempat lain misalnya perpindahan penduduk dari desa ke kota, perpindahan penduduk dari suatu propinsi ke propinsi lain, dari pulau satu ke pulau lain, dan dari negara satu ke negara lain. Hal yang melatar belakangi munculnya mobilitas penduduk menurut Mantra dalam Sudibia (2010) adalah adanya kebutuhan (needs) dan tekanan (stress). Setiap individu mempunyai kebutuhan yang harus dipenuhi. Apabila kebutuhan tersebut tidak dapat dipenuhi terjadilah tekanan (stress) dan tingkatan stress ini berbeda antara satu orang dengan yang lainnya.

Kemudian Mantra (1992) juga menjelaskan bahwa motivasi utama orang melakukan perpindahan dari daerahnya (pedesaan) ke perkotaan adalah motif ekonomi. Kondisi yang paling dirasakan menjadi pertimbangan rasional, dimana individu melakukan mobilitas ke kota adalah adanya harapan untuk memperoleh pekerjaan dan memperoleh pendapatan yang lebih tinggi daripada yang diperoleh di desa. Hubungan antara kebutuhan dan pola mobilitas penduduk dapat dilihat pada gambar sebagai berikut : 


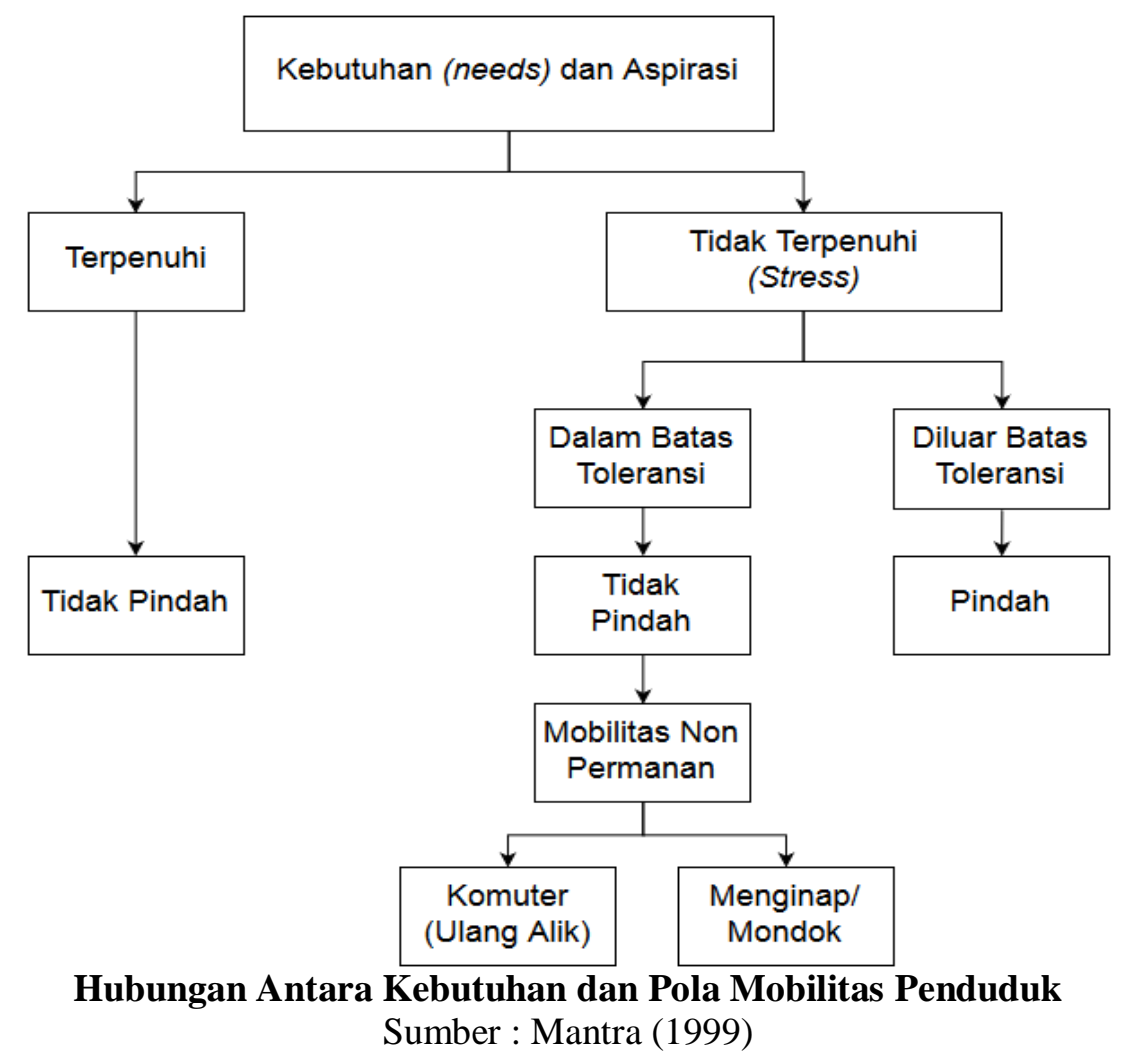

Perbedaan antara mobilitas dan migrasi penduduk, menurut Tjiptoherijanto (1997) mobilitas penduduk didefinisikan sebagai perpindahan penduduk yang melewati batas administratif tingkat II, namun tidak berniat menetap di daerah yang baru, sedangkan migrasi didefinisikan sebagai perpindahan penduduk yang melewati batas administratif tingkat II dan sekaligus berniat menetap di daerah yang baru tersebut.

Mobilitas tempat tinggal (residental mobility) menurut Turner dalam Yunus (2004) terdapat 4 (empat) macam dimensi yang perlu diperhatikan yaitu dimensi lokasi berkaitan dengan jarak dan tempat kerja, dimensi perumahan berkaitan tempat tinggal, dimensi siklus kehidupan berkaitan dengan tahap siklus kehidupannya, dimensi penghasilan berkaitan dengan nilai pendapatan. Komutasi (Commutation) adalah gerak penduduk ulang alik antara tempat tinggal dan tempat tujuan, baik untuk bekerja maupun untuk lain - lain tujuan seperti bersekolah, gerak ulang alik adalah gerak keluar dan kembali dari daerah asal ke daerah tujuan secara teratur dalam selang waktu beberapa jam atau sekitar 6 jam sampai satu hari 24 jam dengan tidak berniat pindah (Idrus:1990). Sedangkan menurut Mantra (2000) komuter disebut juga sebagai nglaju adalah gerak penduduk dari daerah asal menuju ke daerah tujuan dalam batas waktu tertentu dan kembali ke daerah asal pada hari itu juga.

Menurut Mantra (2000) komuter disebut juga sebagai nglaju adalah gerak penduduk dari daerah asal menuju ke daerah tujuan dalam batas waktu tertentu dan kembali ke daerah asal pada hari itu juga. Pada umumnya penduduk yang melakukan mobilitas ingin kembali ke daerah asal secepatnya sehingga kalau di bandingkan frekuensi penduduk yang melakukan mobilitas ulang alik, menginap/mondok dan migrasi, frekuensi mobilitas penduduk ulang alik terbesar disusul oleh menginap/mondok dan migrasi. Orang yang melakukannya disebut komuter (commuter) atau penglaju. 
Kelompok komuter atau penglaju, menurut Tamin (2008) biasanya memilih untuk bertempat tinggal pada daerah belakang (hinterland) yang berada di sekitar kota induknya. Kebanyakan dari mereka memiliki pekerjaan di kota induk sehingga sehari-hari mereka menjadi penglaju atau komuter dan melakukan pergerakan ulang - alik tiap harinya. Pergerakan komuter hanya dibatasi pada aktivitas bekerja yang diklasifikasikan sebagai klasifikasi pergerakan akibat aktivitas ekonomi. Peri urban menurut Bryant dalam Sari (2007) merupakan zona di area transisi desa kota yang disebutnya sebagai regional city yaitu suatu wilayah yang di dalamnya tidak hanya meliputi area dengan fungsi rural, tetapi juga fungsi urban serta percampuran antara keduanya.

Yunus (2008) mengemukanan 4 zona bingkai pada wilayah peri urban yang dapat diterapkan pada kota yang sedang berkembang di negara yang sedang berkembang, diantaranya adalah :

a. Zona bingkai kota (Zobikot), dengan rentang nilai >75\% sampai dengan $<100 \%$ lahan kekotaan, dan $>25 \%$ sampai dengan $>0 \%$ lahan kedesaaan.

b. Zona bingkai kota desa (Zobikodes), dengan rentang nilai 50\% sampai dengan $<75 \%$ lahan perkotaan dan $>25 \%$ sampai dengan $<75 \%$ lahan kedesaan.

c. Zona bingkai desa kota (Zobidekot), dengan rentang nilai $>50 \%$ sampai dengan $<75 \%$ lahan kedesaan dan $<50 \%$ sampai dengan $>25 \%$ lahan perkotaan.

d. Zona bingkai desa (Zobides), dengan rentang nilai $>75 \%$ sampai dengan $100 \%$ lahan kedesaan, dan $<25 \%$ sampai dengan $>0 \%$ lahan perkotaan.

\section{METODE PENELITIAN}

Lokasi penelitian ini berada di Kecamatan Mangkubumi (Kota Tasikmalaya) dan Kecamatan Singaparna (Kabupaten Tasikmalaya). Metode penelitian yang digunakan adalah metode penelitian kualitatif. metode penelitian ini digunakan untuk meneliti pada kondisi obyek yang alamiah, dimana peneliti adalah sebagai instrumen kunci, teknik pengumpulan data dilakukan secara triangulasi (gabungan), analisis data bersifat induktif, dan hasil penelitian kualitatif lebih menekankan makna dari pada generalisasi.

Narasumber dalam penelitian ini berjumlah 18 orang yang di bagi dalam zona bidang yaitu zona bidang desa (Zobides) berjumlah 3 orang yang berada di Desa Cikunten, Desa Sukaherang dan desa Sukaasih; zona bidang desa kota (Zobides) berjumlah 7 orang yang berada di Desa Singaparna, Desa Singasari, Desa Sukamulya, Desa Cipakat, Desa Cintaraja, Desa Cikunir dan Desa Cikadondong; zona bidang kota desa (Zobikodes) berjumlah 5 orang yang berada di Kelurahan Cipawitra, Kelurahan Cipari, Kelurahan karikil, Kelurahan Ciantang dan Kelurahan Mangkubumi; dan zona bidang kota (Zobikot) berjumlah 3 orang yang berada di Kelurahan Linggajaya, Kelurahan Sambongpari dan Kelurahan Sambongjaya.

Nara Sumber Per Zona Bidang Wilayah Peri Urban Kota Tasikmalaya dan Kecamatan Singaparna - Kabupaten Tasikmalaya

\begin{tabular}{|c|c|c|c|c|}
\hline Kecamatan & $\begin{array}{c}\text { Zona } \\
\text { Bidang Wilayah }\end{array}$ & Desa - Kelurahan & $\begin{array}{c}\text { Inisial } \\
\text { Narasumber }\end{array}$ & $\begin{array}{c}\text { Jumlah } \\
\text { Narasumber }\end{array}$ \\
\hline
\end{tabular}




\begin{tabular}{|l|l|l|c|c|}
\hline & Peri Urban & & & \\
\hline Singaparna & Zobides & Desa Cikunten & G & 1 \\
& & Sesa Sukaherang & IK & 1 \\
& & Desa Sukaasih & R & 1 \\
\cline { 2 - 5 } & Zobikdekot & Desa Singaparna & B & 1 \\
& & Desa Singasari & MM & 1 \\
& & Desa Sukamulya & EF & 1 \\
& & Desa Cipakat & EW & 1 \\
& & Desa Cintaraja & DA & 1 \\
& & Desa Cikunir & AM & 1 \\
\hline Mangkubumi & Zobikodes & Desa Cikadondong & EM & 1 \\
& & Kel. Cipawitra & EY & 1 \\
& & Kel. Cipari & E & 1 \\
& & Kel. Karikil & YSA & 1 \\
\cline { 3 - 5 } & & Kel. Cigantang & EB & 1 \\
& & Kel. Mangkubumi & U & 1 \\
& & Kel. Linggajaya & SNA & 1 \\
\hline Jumlah & Kel. Sambongpari & & 18 \\
\hline
\end{tabular}

Sumber : Penelitian 2016

Sumber data penelitian dalam penelitian ini mengggunakan 2 (dua) jenis sumber data, yaitu data primer dan data sekunder. Data primer didapatkan dari hasil wawancara, dan data sekunder berasal dari studi literatur yang di dapat dari buku dan jurnal penelitian. Sedangkan teknik pengumpulan data dalam penelitian ini terdiri dari observasi dan wawancara.

Teknik pengolahan data dalam penelitian ini, data lapangan atau data mentah berupa data lisan dan data tertulis serta foto. Data lisan dan tertulis diperoleh melalui wawancara terhadap responden atau narasumber. Data yang berupa foto merupakan data yang berfungsi mendeskripsikan suatu hal, dapat berupa benda, maupun kejadian saat observasi maupun saat pengumpulan data. Sedangkan teknik analisis data dalam penelitian ini dilakukan dengan cara mereduksi data dan triangulasi.

\section{HASIL DAN PEMBAHASAN}

\section{A. Karakteristik Demografis}

Jenis kelamin merupakan unsur awal pembeda dalam melihat aktifitas mobilitas penduduk ulang alik. Hal ini menunjukkan suatu bentuk pembeda antara sex dan gender dalam melakukan mobilitas penduduk ulang alik. Sex adalah identitas secara fisik berdasarkan jenis kelamin sedangkan gender adalah peran individu dan kemampuan dari jenis kelamin masing masing - masing. Sex dalam hal ini tidak dapat dipertukarkan namun gender dapat saling menggantikan posisi antara yang satu dengan yang lainnya. 
Jenis kelamin yang menjadi pelaku mobilitas penduduk ulang alik pada wilayah peri urban antara Kecamatan mangkubumi (Kota Tasikmalaya) dan Kecamatan Singaparna (Kabupaten Tasikmalaya) terdiri dari 2 yaitu jenis kelamin laki - laki dan jenis kelamin perempuan. Jenis kelamin perempuan lebih banyak dibandingkan jumlah jenis kelamin laki - laki. Jenis jenis kelamin perempuan dengan jumlah 10 orang dan sisanya adalah berjenis kelamin laki - laki berjumlah 8 orang. Jenis kelamin laki - laki di dominasi pada wilayah zona bidang kota (Zobidekot) sebanyak 4 orang dan perempuan pada zona bidang kota desa (Zobikodes) sebanyak 5 orang.

Kemampuan antara laki - laki dan perempuan dalam melakukan mobilitas penduduk tentunya berbeda. Hal ini dapat dilihat dari jenis pekerjaan yang dilakukan dari tiap individu itu sendiri dan juga jumlah waktu yang digunakan untuk bekerja. Semakin jauh perjalanan mobilitasnya tentunya membutuhkan ketahanan fisik yang baik dan juga memperhitungkan aspek pengeluaran untuk biaya transportasi itu sendiri. Sedangkan jumlah waktu yang digunakan untuk bekerja, antara laki - laki dan perempuan lebih banyak dilakukan oleh laki - laki. Wanita memiliki waktu sedikit di tempat kerja terutama yang bekerja di sektor formal. Dan wanita juga memiliki beban waktu untuk mengurus keluarganya.

Usia pelaku mobilitas penduduk ulang alik di wilayah peri urban antara Kecamatan Mangkubumi (Kota Tasikmalaya) dan Kecamatan Singaparna (kabupaten tasikmalaya) dengan rentang usia $20 \mathrm{~s} / \mathrm{d} 49$ tahun, yang paling tinggi berusia $25 \mathrm{~s} / \mathrm{d} 29$ tahun dengan jumlah 6 orang dan yang paling sedikit adalah pada usia $20 \mathrm{~s} / \mathrm{d} 24$ tahun berjumlah 1 orang dan usia $40 \mathrm{~s} / \mathrm{d} 44$ tahun berjumlah 1 orang. Usia produktif penduduk adalah usia kerja yang sudah bisa menghasilkan barang dan jasa. Usia berdasarkan beban tanggungan berdasarkan Badan Pusat Statistik (BPS) adalah angka yang menyatakan perbandingan antara penduduk usia tidak produktif (di bawah 15 tahun dan 65 tahun ke atas) dengan usia produktif (antara 15 sampai 64 tahun) dikalikan 100. Dalam hal ini usia pelaku mobilitas penduduk ulang alik yang ada di wilayah peri urban khususnya Kecamatan Mangkubumi (Kota Tasikmalaya) dan Kecamatan Singaparna (Kabupaten Tasikmalaya) masuk dalam kategori usia produktif. Latar belakang keluarga pelaku mobilitas penduduk ulang alik yang paling sama banyaknya antara pendatang dengan jumlah 9 orang dan bukan pendatang dengan jumlah 9 orang. Latar belakang keluarga ini mencerminkan jumlah penduduk secara alamiah pada suatu wilayah.

Penduduk pendatang dikategorikan secara individu (pelaku mobilitas) sebagai orang yang berasal dari luar wilayah itu sendiri. Hal utamanya yang berpengaruh adalah dari perkawinan dan migrasi penduduk. Proses perkawinan biasanya akan mengikuti si suami dan si istri dimana dia tinggal sedangkan dalam bentuk migrasi biasanya dalam bentuk individu dan keluarga akan mencari daerah yang baru untuk dijadikan tempat tinggal. Sedangkan yang dimaksud penduduk bukan pendatang adalah dia (pelaku mobilitas) merupakan penduduk asli dari daerah itu sendiri yang sudah tinggal lama dari sejak lahir hingga dewasa. Namun penduduk asli dalam hal ini juga memilih pekerjaan yang berada di luar wilayah tempat tinggalnya dengan kata lain melakukan mobilitas ulang alik dari tempat tinggalnya.

Menurut Mantra (2000) orang (individu) yang melakukan mobilitas penduduk secara ulang alik di sebut sebagai komuter atau penglaju. Pada mobilitas penduduk ulang alik yang menjadi pelaku mobilitas penduduk ulang alik biasanya tergantung jenis aktifitas, waktu dan pola perjalanan yang ada. Hal ini juga terkait dengan 
status individu itu dalam keluarga.Yang menjadi pelaku mobilitas penduduk ulang alik pada wilayah peri urban antara Kecamatan Mangkubumi (Kota Tasikmalaya) dan Kecamatan Singaparna (Kabupaten Tasikmalaya) adalah laki - laki yang berstatus sudah kawin dan sebagai suami, perempuan yang berstatus sudah kawin sebagai istri, laki - laki yang berstatus belum kawin dan perempuan yang berstatus belum kawin.

Laki - laki yang berstatus sebagai suami atau kepala keluarga biasanya melakukan mobilitas penduduk secara ulang alik lebih banyak ketimbang wanita yang berstatus sebagai istri. Hal ini disebabkan karena laki - laki sebagai suami yang merupakan pekerja utama dalam sebuah keluarga dan juga tulang punggung dalam keluarga. Sedangkan wanita yang berstatus sebagai istri dalam melakukan mobilitas penduduk ulang alik biasanya bekerja sebagai pelengkap. Namun di sisi lain juga ada juga wanita yang menjadi tulang punggung dalam keluarga sehingga pendapatan yang di terima oleh istri lebih besar ketimbang pendapatan yang diterima suami. Sedangkan pada pelaku mobilitas penduduk ulang alik bagi yang belum berstatus baik laki - laki dan perempuan, dalam sistem pekerjaan dan pendapatannya lebih mementingkan untuk pemenuhan kebutuhan individu itu sendiri. Hal ini lah yang menjadi motivasi dalam melakukan mobilitas penduduk secara ulang alik yaitu untuk mendapatkan pendapatan dalam bentuk motivasi ekonomi menurut Mantra (1992).

Status perkawinan pelaku mobilitas penduduk ulang alik pada wilayah peri urban antara Kecamatan Mangkubumi (Kota Tasikmalaya) dan Kecamatan Singaparna (Kabupaten Tasikmalaya) yang paling banyak adalah 13 orang dengan status kawin, di dominasi pada zona bidang desa kota (Zobidekot) dengan jumlah 5 orang. Jumlah pelaku dengan berdasarkan jenis kelamin dan status perkawinan, untuk jenis kelamin laki - laki yang berstatus sudah kawin berjumlah 7 orang, jenis kelamin perempuan yang berstatus sudah kawin berjumlah 5 orang, jenis kelamin laki - laki yang berstatus belum kawin berjumlah 1 orang dan jenis kelamin wanita yang berstatus belum kawin berjumlah 4 orang. Yang paling banyak melakukan mobilitas ulang alik dalam sebuah keluarga adalah laki - laki yang bertatus keluarga sebagai suami dan belum belum kawin berjumlah 13 orang. Pelaku mobilitas penduduk ulang alik dalam sebuah keluarga biasanya dilakukan secara individu dan berkelompok. Individu maksudnya adalah bentuk perseorangan pergerakan dan perpindahan dalam melakukan mobilitas sedangkan dalam bentuk kelompok maksudnya adalah aktifitas mobilitas ini dilakukan bersama dengan anggota keluarga lainnya. Adapun jumlah mobilitas penduduk ulang alik yang dilakukan secara bersamaan hanya terdiri dari 1 orang saja karena berpergian menggunakan kendaraan secara bersama anggota keluarga dan yang lainnya melakukan secara sendiri terpisah dengan anggota keluarganya dengan menggunakan kendaraan masing - masing.

Perbedaan antara individu yang sudah berkeluarga dan belum berkeluarga terletak pada kebutuhan secara individu itu sendiri dan individu itu di dalam keluarga. Secara kebutuhan individu itu sendiri, kebutuhan dalam mobilitas penduduk secara ulang alik tentunya hanya sebatas keperluan biaya transportasi sendiri dalam melakukan pergerakan dan perpindahan, baik itu individu yang menggunakan kendaraan pribadi seperti sepeda motor (roda dua) serta mobil (roda empat) dan juga angkutan umum. Sedangkan individu dalam keluarga mengacu pada pengeluaran yang dijadikan kebutuhan utama dalam keluarga. Jika anggota keluarga 
berjumlah banyak tentunya mempengaruhi juga biaya yang harus dibagi juga dengan biaya transportasi yang digunakan untuk melakukan aktifitas mobilitas penduduk secara ulang alik

\section{B. Karakteristik Sosial Ekonomi}

Karakteristik sosial yang berpengaruh dalam mobilitas penduduk ulang alik adalah dari segi tingkat pendidikan dan jenis pekerjaan. Dalam hal ini tingkat pendidikan dapat berubah secara statusnya dan jenis pekerjaan juga dapat berubah secara statusnya.

Tingkat pendidikan dari pelaku mobilitas penduduk ulang alik di wilayah peri urban antara Kecamatan Mangkubumi (Kota Tasikmalaya) dan Kecamatan Singaparna (Kabupaten Tasikmalaya) antara lain SMA/ SMK, pendidikan strata 1 (sarjana) dan pendidikan strata 2 (pascasarjana). Yang paling banyak melakukan mobilitas penduduk ulang alik adalah pendidikan strata 1 (sarjana) dengan jumlah 13 orang terutama pada wilayah zona bidang desa kota (Zobikdekot) dengan jumlah 5 orang dan yang paling rendah adalah pendidikan strata 2 (pascasarjana) dengan jumlah 2 orang yang berada di zona bidang kota desa (Zobikodes). Tingkat pendidikan yang dimiliki oleh pelaku mobilitas penduduk ulang alik tentunya berhubungan dengan jenis pekerjaan yang nantinya dilakukan.

Jenis pekerjaan dari pelaku mobilitas penduduk ulang alik di wilayah peri urban antara Kecamatan Mangkubumi (Kota Tasikmalaya) dan Kecamatan Singaparna (Kabupaten Tasikmalaya) antara lain karyawan swasta, wirausaha, pegawai negeri sipil (PNS), guru dan dosen. Jenis pekerjaan yang paling banyak adalah pelaku wirausaha sebanyak 7 orang terutama pada zona bidang desa kota sebanyak 5 orang dan yang paling sedikit adalah pegawai negeri sipil (PNS) berjumlah 1 orang yang berada di zona bidang desa (Zobides).

Pelaku mobilitas penduduk ulang alik dalam memilih lokasi tempat kerja di pengaruhi oleh jarak dan waktu tempuh perjalanan. Dari tiap individu secara karakteristik tidak sama dalam melakukan mobilitas penduduk untuk melakukan mobilitas ulang alik. Pemilihan jenis pekerjaan dan lokasi pekerjaan ini di lakukan untuk memenuhi kebutuhan pendapatan individu si pelaku mobilitas.

Tempat yang dituju sebagai tempat kerja dalam mobilitas ini dapat dilakukan dengan sekali tempuh perjalanan menggunakan kendaraan. Berdasarkan jenisnya kendaraan pribadi dan kendaraan umum. Kendaraan pribadi yang menggunakan mobil dan sepeda motor dapat melakukan sekali perjalanan ke tempat kerja. Sedangkan bagi pelaku mobilitas penduduk ulang alik pengguna kendaraan umum harus bergantian menggunakan jenis angkutan yang satu dengan yang lainnya. Dan dengan menggunakan kendaraan pribadi atau pun umum nantinya tiap pelaku dapat melakukan perjalanan dari tempat lokasi kerja tersebut ke lokasi kegiatan yang lainnya

Menurut Mantra dalam Sudibia (2010) adalah adanya kebutuhan (needs) dan tekanan (stress). Setiap individu mempunyai kebutuhan yang harus dipenuhi. Apabila kebutuhan tersebut tidak dapat dipenuhi terjadilah tekanan (stress) dan tingkatan stress ini berbeda antara satu orang dengan yang lainnya. Maka dengan adanya pemenuhan kebutuhan baik secara individu dan individu itu didalam 
keluarga, individu melakukan mobilitas penduduk ulang alik. Tempat yang dituju sebagai tempat kerja dalam mobilitas ini dapat dilakukan dengan sekali tempuh perjalanan menggunakan kendaraan. Berdasarkan jenisnya kendaraan pribadi dan kendaraan umum. Kendaraan pribadi yang menggunakan mobil dan sepeda motor dapat melakukan sekali perjalanan ke tempat kerja. Sedangkan bagi pelaku mobilitas penduduk ulang alik pengguna kendaraan umum harus bergantian menggunakan jenis angkutan yang satu dengan yang lainnya. Dan dengan menggunakan kendaraan pribadi atau pun umum nantinya tiap pelaku dapat melakukan perjalanan dari tempat lokasi kerja tersebut ke lokasi kegiatan yang lainnyaDengan adanya pengaruh jarak dan waktu perjalanan dalam melakukan mobilitas ulang alik terkadang menimbulkan suatu gejala stress. Stress dalam perjalanan mobilitas terbentuk sebagai akibat ketidakmampuan individu menerima kondisi perjalanan yang tidak seimbang. Kondisi perjalanan yang tidak seimbang dalam hal ini bisa berbentuk ketidak lancaran dalam melakukan perjalanan seperti kemacetan lalu lintas, kesemrawutan lalu lintas dan pengaruh kondisi cuaca. Namun gejala stress tidak di alami pada pelaku mobilitas penduduk ulang alik untuk jarak pendek sehingga bisa mempersingkat waktu perjalanan.

Dalam mobilitas penduduk ulang alik, rutinitas pergerakan dan perpindahan secara harian tentunya membutuhkan waktu yang seimbang. Pembagian waktu dan aktifitas ini tergantung dari tiap kebutuhan individu. Semakin tinggi tingkat mobilitas penduduk ulang alik yang dilakukan maka semakin tinggi juga tingkat kebutuhan waktu yang dipergunakan. Untuk secara keseluruhan dari pelaku mobilitas penduduk ulang alik yang ada di wilayah peri urban masih dapat memiliki waktu luang.

Mobilitas penduduk ulang alik yang terkait dengan interaksi dalam keluarga, tidak semua pelaku mobilitas memiliki waktu untuk bisa berkumpul kembali dengan keluarga. Hal ini disebabkan waktu yang digunakan ditempat kerja lebih lama ketimbang yang ada dirumah dan ditambah waktu perjalanan kembali dari tempat kerja menuju tempat tiggal. Dalam pemanfaatan waktu tegantung jenis pekerjaan yang dilakoni. Semakin tinggi jenis pekerjaan yang dilakukan maka peluang waktu untuk berkumpul dengan keluarga semakin kecil. Namun dalam hal ini tidak akan mengurangi waktu untuk bisa berkumpul bersama.

Sedangkan untuk kegiatan lainnya dari pelaku mobilitas penduduk ulanG alik masih memiliki peluang untuk melakukan aktifitas lainnya yang diselingi aktifitas mobilitas penduduk ulang alik. Aktifitas lainnya seperti berbelanja, ke tempat hiburan, bertemu kerabat, dan kegaiatan keagamaan.Pemanfaatan waktu terutama pada sisa jam waktu dari kegiatan bekerja dan juga pada hari libur lainnya. Pada sisa jam kegiatan bekerja, pelaku mobilitas ulang alik dapat bertemu dan berkumpul dengan keluarga. Sedangkan pada hari libur dimanfaatkan untuk melakukan kegaiatan secara bersama keluarga dan menyalurkan hobi kegiatan lainnya.

Tingkat pendapatan dari pelaku mobilitas penduduk ulang alik di wilayah peri urban antara Kecamatan Mangkubumi (Kota Tasikmalaya) dan Kecamatan Singaparna (Kabupaten Tasikmalaya) dengan rincian pendapatan antara Rp. 21.000.000 s/d Rp. 50.000 .000 per tahun. Tingkat pendapatan per tahun dari pelaku mobilitas ulang alik rata - rata yang paling banyak adalah 8 orang dengan tingkat pendapatan Rp. 21.000.000 s/d Rp. 30.000 .000 terutama yang berada di wilayah zona bidang desa kota (Zobikodes) dengan jumlah 4 orang. Dan yang paling sedikit 
tingkat pendapatannya sebanyak 4 orang yang berada di zona bidang desa (Zobides) berjumlah 1 orang, zona bidang desa kota (Zobikodes) berjumlah 1 orang, zona bidang kota desa (Zobikodes) berjumlah 1 orang dan zona bidang kota (Zobikot).

Besaran pendapatan tiap individu yang melakukan mobilitas penduduk ulang alik tergantung dari jenis pekerjaan yang dilakoninya. Semakin besar pendapatan pendapatan yang diterima semakin besar pula tanggung jawab pekerjaan tersebut. Sehingga nilai pendapatan yang di terima dari mobilitas penduduk ulang alik untuk melakukan pekerjaan tersebut bisa saja lebih besar pendapatannya dan pendapatannya masih standar saja. Hal ini nantinya juga berpengaruh terhadap alokasi waktu perjalanan dan biaya perjalanan yang di keluarkan oleh tiap pelaku mobilitas penduduk secara ulang alik.

Dengan adanya besaran yang di terima oleh pelaku mobiltas ulang alik, kelayakan yang di terima tentunya akan jadi penentu kebutuhan hidup keluarga. Semakin besar jumlah anggota keluarga maka semakin tinggi juga tingkat kebutuhan yang anda. Dengan kata lain besaran yang diterima sesuai dengan kemampuan tiap individu. Selain pendapatan individu, pendapatan pasangan keluarga juga mempengaruhi pendapatan ekonomi keluarga secara keseluruhan. Dengan demikian kebutuhan rumah tangga dari pelaku mobilitas penduduk ulang alik dapat terpenuhi.

Waktu yang dipergunakan dalam bekerja dalam hal ini sesuai dengan pendapatan yang di dapatkan. Waktu kerja tiap individu dari pelaku berbeda antara yang satu dengan yang lainnya. Sehingga peluang untuk mendapatkan pendapatan yang besar mempengaruhi produktifitas dalam bekerja.Sedangkan kelayakan pendapatan yang diterima oleh pelaku mobilitas penduduk ulang alik besaran yang diterima dikatakan cukup layak dan sangat layak. Cukup layak dalam hal ini untuk kebutuhan pengeluaran rumah tangga masih kurang dan hampir sesuai. Sedangkan sangat layak berdasarkan nilai pendapatan yang besar terutama dari segi pendapatan tambahan sehingga biaya kebutuhan rumah tangga sehingga dapat terpenuhi.Pendapatan pasangan dalam keluarga dari pelaku mobilitas penduduk ulang alik yang berstatus suami atau pun istri sudah sesuai pendapatan yang diterima untuk memenuhi kebutuhan rumah tangga. Sehingga pengeluaran untuk biaya kebutuhan bisa saling menutupi. Namun untuk pelaku yang berstatus belum bekeluarga untuk pemenuhan keburuhan berasal dari pendapatan sendiri.

\section{KESIMPULAN}

Mobilitas penduduk ulang alik pada wilayah peri urban antara Kecamatan Mangkubumi (Kota Tasikmalaya) dan Kecamatan Singaparna (Kabupaten Tasikmalaya) dipengaruhi oleh karakteristis demografis (Jenis kelamin, usia, status kawin, dan latar belakang keluarga), karakteristik sosial (Tingkat pendidikan dan jenis pekerjaan) dan karakteristik ekonomii (Tingkat pendapatan). Yang menjadi pelaku mobilitas penduduk ulang alik adalah laki - laki yang berstatus sudah kawin dan sebagai suami, perempuan yang berstatus sudah kawin sebagai istri, laki - laki yang berstatus belum kawin dan perempuan yang berstatus belum kawin.

Pelaku mobilitas penduduk ulang alik dalam sebuah keluarga biasanya dilakukan secara individu dan berkelompok. Individu maksudnya adalah bentuk perseorangan pergerakan dan perpindahan dalam melakukan mobilitas sedangkan dalam bentuk kelompok maksudnya adalah aktifitas mobilitas ini dilakukan bersama dengan anggota 
keluarga lainnya. Adapun jumlah mobilitas penduduk ulang alik yang dilakukan secara bersamaan hanya terdiri dari 1 orang saja karena berpergian menggunakan kendaraan secara bersama anggota keluarga dan yang lainnya melakukan secara sendiri terpisah dengan anggota keluarganya dengan menggunakan kendaraan masing - masing.

Perbedaan antara individu yang sudah berkeluarga dan belum berkeluarga terletak pada kebutuhan secara individu itu sendiri dan individu itu di dalam keluarga. Sedangkan individu dalam keluarga mengacu pada pengeluaran yang dijadikan kebutuhan utama dalam keluarga. Jika anggota keluarga berjumlah banyak tentunya mempengaruhi juga biaya yang harus dibagi juga dengan biaya transportasi yang digunakan untuk melakukan aktifitas mobilitas penduduk secara ulang alik.

Laki - laki yang berstatus sebagai suami atau kepala keluarga biasanya melakukan mobilitas penduduk secara ulang alik lebih banyak ketimbang wanita yang berstatus sebagai istri. Hal ini disebabkan karena laki - laki sebagai suami yang merupakan pekerja utama dalam sebuah keluarga dan juga tulang punggung dalam keluarga. Sedangkan wanita yang berstatus sebagai istri dalam melakukan mobilitas penduduk ulang alik biasanya bekerja sebagai pelengkap. Namun di sisi lain juga ada juga wanita yang menjadi tulang punggung dalam keluarga sehingga pendapatan yang di terima oleh istri lebih besar ketimbang pendapatan yang diterima suami. Sedangkan pada pelaku mobilitas penduduk ulang alik bagi yang belum berstatus baik laki - laki dan perempuan, dalam sistem pekerjaan dan pendapatannya lebih mementingkan untuk pemenuhan kebutuhan individu itu sendiri.

Pelaku mobilitas penduduk ulang alik dalam sebuah keluarga biasanya dilakukan secara individu dan berkelompok. Individu maksudnya adalah bentuk perseorangan pergerakan dan perpindahan dalam melakukan mobilitas sedangkan dalam bentuk kelompok maksudnya adalah aktifitas mobilitas ini dilakukan bersama dengan anggota keluarga lainnya. Adapun jumlah mobilitas penduduk ulang alik yang dilakukan secara bersamaan hanya terdiri dari 1 orang saja karena berpergian menggunakan kendaraan secara bersama anggota keluarga dan yang lainnya melakukan secara sendiri terpisah dengan anggota keluarganya dengan menggunakan kendaraan masing - masing.

Perbedaan antara individu yang sudah berkeluarga dan belum berkeluarga terletak pada kebutuhan secara individu itu sendiri dan individu itu di dalam keluarga. Secara kebutuhan individu itu sendiri, kebutuhan dalam mobilitas penduduk secara ulang alik tentunya hanya sebatas keperluan biaya transportasi sendiri dalam melakukan pergerakan dan perpindahan, baik itu individu yang menggunakan kendaraan pribadi seperti sepeda motor (roda dua) serta mobil (roda empat) dan juga angkutan umum. Sedangkan individu dalam keluarga mengacu pada pengeluaran yang dijadikan kebutuhan utama dalam keluarga. Jika anggota keluarga berjumlah banyak tentunya mempengaruhi juga biaya yang harus dibagi juga dengan biaya transportasi yang digunakan untuk melakukan aktifitas mobilitas penduduk secara ulang alik

\section{DAFTAR PUSTAKA}

Firman, Tommy. 1996. Urbanisasi, Persebaran Penduduk dan Tata Ruang di Indonesia. Jurnal Perencanaan Wilayah dan Kota. Bandung : ITB.

Tamin, Ofyar Z. 2008. Perencanaan, Pemodelan, dan Rekayasa Transportasi. Bandung: Penerbit ITB. 
Mantra, Ida Bagus. 1985. Pengantar Studi Demografi. Yogyakarta : Nur Cahaya.

Mantra, Ida Bagus. 2000. Demografi Umum. Yogyakarta : Pustaka Pelajar.

Sudibia, I Ketut. 2010. Mobilitas Penduduk Non Permanen dan Kontribusi Remitan Terhadap Kehidupan Ekonomi dan Sosial Rumah Tangga Di Daerah Asal, Orasi Ilmiah Universitas Udayana. Bali : Universitas Udayana

Sumaatmadja, Nursid. 1981. Studi Geografi Suatu Pendekatan dan Analisis Keruangan. Bandung : Alumni.

Idrus, Muhammad. 2007. Metode Penelitian Ilmu Sosial Pendekatan Kualitatif dan Kuantitatif. Jakarta : Erlangga.

Sari, Maulien Khairina dan Winarso, Hadi. 2007. Transformasi Sosial Ekonomi Masyarakat di Sekitar Pengembangan Lahan Skala Besar. Kasus Bumi Serpong Damai. Jurnal Perencanaan Wilayah dan Kota. Vol.18 No.1, hal 1-30.

Yunus, Hadi Sabari . 2008. Dinamika Area Peri Urban : Faktor Penentu Masa Depan Kota. Yogyakarta : Pustaka Pelajar. 